\title{
Formation of the Engineering Staff Training System for Military Shipbuilding in Leningrad Higher Education Institutions (1920-1930)
}

\author{
V. N. Polovinkin \\ Krylov State Research Centre \\ St. Petersburg, Russia
}

S. V. Fedulov

\author{
Military Space Academy named after A.F. Mozhaysky \\ St. Petersburg, Russia \\ serg.val.fed.661000@yandex.ru
}

\author{
B. A. Barbanel \\ Research Society of Shipbuilders named after A.N. Krylov \\ St. Petersburg, Russia \\ cpntokrylov@mail.ru
}

\section{S. Riaskov}

Saint Petersburg Electrotechnical University «LETI»

St. Petersburg, Russia

yanryaskov@gmail.com

\begin{abstract}
As a result of the cataclysms caused by the First World War, the Civil War, the revolution, and the intervention, shipbuilding enterprises lost qualified engineering staff. The state staff training system required the reorganization. Historically, Leningrad was the leading research center of the country, where the country's leading educational institutions were located. Therefore, the city became the place for organization of training system for military shipbuilding. Firstly, the Naval Academy established the Military Industrial Department, and then civilian universities and the Naval Engineering School started training staff for the shipbuilding industry.
\end{abstract}

Key words-Naval Academy; Military Industrial Department; engineering staff; shipbuilding enterprises

\section{INTRODUCTION}

In 1920-1930 in the Soviet Russia was being created a socialist system of public education, was being formed a new intelligentsia, was being affirmed a Marxist-Leninist ideology, and life was being rebuilt on the background of the industrial transformation of the society. For one decade, the country's leadership had to endure not only revolutionary changes in absolutely all spheres of life, but also to withstand the Civil War, intervention, to unite the multinational republics in the Union, to stand such an exceptional events in history of mankind, as military communism, NEP, the struggle for an atheistic state and collectivization.

The revolution, the Civil War and the intervention of the former allied countries led to a huge drop in the level of staff training in all areas, and not only in military shipbuilding. The number of the old specialists was extremely small, and also they were not trusted and suspected of all kinds of hostile designs. Everyone urgently recognized the need for a hasty solution to the task of obtaining a sufficient number of engineering staff.

\section{FORMATION OF THE ENGINEERING STAFF TRAINING SYSTEM FOR MILITARY SHIPBUILDING}

Creation of the Soviet Higher Education started from the decree of the August 2, 1918 "On the rules for admission to higher educational institutions of the RSFSR." The decree eliminated the existing restrictions in pre-revolutionary Russia on the entry of workers and peasants to the universities. Now, every person over 16 years old, regardless of citizenship and nationality, gender and religion, could enroll to the universities without exams; documents about secondary education were not required as well. The advantage in enrollment was given to the workers and the poorest peasantry. However, the new admission rules did not give workers a real opportunity to study at a university, since they did not have a secondary education [1]. To solve this problem, everywhere, in all universities of the country, the government started creation of "rabfaks", and in HEIs-preparatory classes in which representatives of workers and peasants could prepare for higher education.

Leningrad was rightfully considered as a research and production cluster of military shipbuilding. Not only the largest shipbuilding enterprises were concentrated in the city, but also civilian and military educational institutions that trained engineering staff for them. The leading role in training of highly qualified specialists was assigned to the Naval Academy.

May 10-16, 1929 in Moscow, the head of the Naval Forces of the Red Army R.A. Muklevich held a meeting at which a report was heard by the head of the Military Academy, Professor B.B. Gervais on the activities of the Academy [2, p. 10-11]. With regard to the activities of the Academy, the meeting adopted a decision, the main provisions of which were as follows: "The Academy needs to achieve a unity of understanding among the students of the role and construction of the Naval Forces; the work of the Academy should be brought closer to the actual conditions of the Red Army naval 
forces; Academy should provide all possible assistance to industry through the replenishment of naval specialists" [2, p. 10-11].

On June 17, 1929, the Military Naval Academy held an interdepartmental meeting on the issue of training engineers at the academy for the naval industry. The meeting recognized the possibility of starting in autumn of 1929 a one-year specialization of engineers in torpedoes, mines and trawls, in artillery fire control devices ( 7 people in each group) and in naval artillery installations. The following target setting was adopted: in the courses to train civil engineers for work in design bureaus and in the factories of the naval industry in design, creation, testing and delivery of samples of weapons [3]. Thus, it was decided to create a Military Industrial Branch in Military Academy.

The leadership of the academy adopted a meeting decision. Since 1929, for the first time, training for civilians - engineers for the defense and shipbuilding industries involved in the construction of ships - began at the Academy. So, on October 22, 1929, the Mobilization Department of the 2nd Division of the Supreme Council of the National Economy sent the chief and commissioner of the Naval Aviation Administration: "To implement the order of the Revolutionary Military Council, it is urgently proposed no later than October 31, 1929 years, to collect for the military production service outfit from the attached list of engineers and send 25 people to the Baltic Fleet crew for further deployment to the Military Naval Aviation the most satisfactory in social terms, by profession and corresponding to the requirements of target settings and training programs for engineers for the naval industry "[4, p. 16].

In his report of January 30, 1929, the head of the Military Aviation Administration informed the USSR Supreme Economic Council on Mobilization and Planning that the selection of civil engineers for the naval industry was over. 29 engineers had arrived and had been trained at the Academy [4, p. 16]. At the same time, the conditions for staying of civilian specialists (who were awarded the military rank of "Red Navy Engineer" - author's note) were difficult, a lot had to be done for the first time, the system was not debugged, and the students themselves had not even completed the initial training.

In order to solve this problem and in accordance with the decree of the Supreme Economic Council, the head of the Mobilization Industry Division of the Leningrad Regional Council of the National Economy has determined the procedure for sending young engineers trained at the Academy to military enterprises. Namely: to the plants of Mashtrest 9 people, to the plants of Sudotrest -8 people, to the factory of Ostekhbyuro -9 people, to the plants of Orudatrest -3 people. At the same factories, they implemented practical training. During their stay at the Academy (from December 1, 1929 to October 1, 1930), the above mentioned enterprises paid each of them an allowance in the amount of the 1st category of the technical tariff grid - 120-125 rubles per month [4, p. 42].

At the same time, in Leningrad in 1932, there were 32 industrial and research institutions engaged directly or related to the construction of military ships [5, p. 70-75]. Therefore, on June 13, 1932, at a meeting at the 2nd Personnel Sector of the People's Commissariat of Heavy Industry of the USSR on the issue of the Academy, the following resolution was adopted: "Until the normal graduation of engineers of shipbuilding, steam, diesel specialties at the Leningrad Shipbuilding Institute to keep those at the Academy [6, p. 155]. And already in September 1932, the commander of the Naval Forces of the Red Army and the chairman of the Strategic Missile Forces of the USSR approved the "Regulations on the HE of the Military Academy of the Red Army" [7, p. 128].

In accordance with the "Regulation ..." the goal of the Academy was to prepare specialist - engineers for enterprises and industrial institutions that fulfill the orders of the Navy. The target setting was the training of engineers for work in design and testing bureaus, in industrial plants.

During the existence of the HE of the Academy, according to the authors' calculations, graduates of the following technical colleges were enrolled: Leningrad Polytechnic Institute, Leningrad Technological Institute, Leningrad Electrotechnical Institute, Leningrad Technological Institute, Leningrad Boiler and Turbine Institute, Leningrad Engineering Institute, Moscow Mechanical Institute, Moscow Institute of Mechanical Engineering, Moscow Power Engineering Institute, etc. [1]

The number and specialization of students can be judged from Table 1.

TABLE I. SPECIALIZATION AND THE AMOUNT OF STUDENTS [1]

\begin{tabular}{|c|c|c|c|c|c|c|c|}
\hline \multirow[t]{2}{*}{ Specialty } & \multicolumn{7}{|c|}{ Quantity of students } \\
\hline & 1929 & $\begin{array}{c}193 \\
0\end{array}$ & 1931 & 1932 & 1933 & 1934 & 1935 \\
\hline Gun mount & 4 & 7 & 12 & 15 & - & - & - \\
\hline torpedoed & 10 & 10 & 12 & 15 & - & - & - \\
\hline minesweeping & - & 8 & 12 & 15 & - & - & - \\
\hline $\begin{array}{l}\text { Fire } \\
\text { maintenance }\end{array}$ & 4 & 17 & 12 & - & - & - & - \\
\hline mines & 3 & - & - & 15 & - & - & - \\
\hline Naval arms & 21 & 42 & 48 & 60 & $41 *$ & $44 *$ & $15^{*}$ \\
\hline $\begin{array}{l}\text { Military } \\
\text { engineering }\end{array}$ & - & 11 & 25 & 25 & - & - & - \\
\hline shipbuilding & - & 4 & 12 & 15 & 42 & 35 & - \\
\hline total & 21 & 57 & 85 & 100 & 83 & 79 & 15 \\
\hline
\end{tabular}

In total, based on archival documents according to the calculations of the authors, it was determined that 440 design scientists and highly qualified industrial engineers were trained at the Academy from 1929 to 1935 . After graduation from the Academy, graduates were enrolled in the reserve of the Red Army and were sent to the engineering and technical posts at enterprises and institutions of military shipbuilding.

\section{DEVELOPMENT OF THE ENGINEERING TRAINING SYSTEM FOR MILITARY SHIPBUILDING}

However, this was clearly not enough. The Inspection of the Naval Forces of the Red Army working in 1932 at the enterprises of the military shipbuilding industry indicated that the majority of the identified shortcomings are the small number and extremely low training of engineering staff and the administration of the plants. This is eloquently evidenced by the plan for the need for engineering and technical personnel drawn up on the basis of the materials of the Leningrad group 
of military shipbuilding factories, which was expressed in the following figures: $1931 / 32-207$ engineers and 479 technicians, 1932/33 - 178 engineers and 669 technicians. In three years -552 engineers and 1724 technicians [8].

After 1934, enrollment to the Academy had stopped. This was due to the fact that since 1934, the Academy began to carry out special recruitment for the faculty of Naval Weapons and Shipbuilding. Special equipment and they had a target setting for the training of design engineers [9, p. 64]. According to the special recruitment, citizens from the age of 21 to 30 years old, which graduated from ten-year schools, labor schools, technical schools, and four courses of universities and passed competitive entrance exams after special selection, were admitted. After entering the Naval Aviation Administration, they were in the position of cadets for 4-5 months, where they underwent initial military training, and after passing the corresponding tests they were enrolled in the students and received the rights and position of the commanding staff $[10$, p. 27]. Thanks to the special recruitment, it was prepared: in 1936 - 75 people, in 1937 189 people, in 1938 - 177 people. Total - 441 highly qualified specialists $[9$, p. 40]. In total, taking into account the graduates of Academy and special military equipment, the Naval Aviation Institute, according to the authors, there were prepared 881 design engineers, production engineers in the following specialties: artillery, mine and torpedo, shipbuilding, machine-building, and electrical engineering for enterprises and institutions of military shipbuilding. Many of them subsequently became prominent designers, managers and organizers at enterprises, and also became heads of departments and faculties of the Military Academy [3].

It should be noted that the training of specialists for shipbuilding in the 1920s was carried out in two directions:

- Higher military educational institutions - Naval Academy, Higher Naval Engineering School, both in Leningrad;

- Civil Higher Technical Educational Institutions Leningrad Electrotechnical Institute, shipbuilding department of the Leningrad Polytechnic Institute.

A characteristic drawback of this training on the eve of the first five-year plan was that these areas were fragmented and did not have a unified system of training. In addition, for civilian technical colleges it was inherent:

- the small number of graduates, for example, the shipbuilding faculty of the Leningrad Polytechnic Institute from 1902 to 1930 . A total of 453 engineers were graduated [1];

- the long duration of student training at the University of Higher Technical Education (6-8 years) [1].

At the same time, in the interests of the fleet, it was planned to prepare in civilian universities: the Leningrad Polytechnic Institute - 392 people (of which: the Shipbuilding Department 242 people, the Mechanical Department - 150 people); Leningrad Technological Institute (Department of Chemistry) 465 people; Leningrad Institute of Railway Engineers (water communications department) - 335 people; Leningrad Electrotechnical Institute (LETI) - 582 people). In total - 1779 people [11, p. 2].
Creation and further development of a training system for engineering and technical staff for military shipbuilding was largely facilitated by the constant attention on the part of state authorities both in the center and in the localities. So, for example, on January 7, 1929, at a meeting of the Leningrad Regional Committee of the All-Union Communist Party of Bolsheviks, the question of training specialists for industry at the Naval Academy [1] was considered, where it was decided to entrust the factions of the All-Union Communist Party of Bolsheviks to study the issue of providing military industry engineers, specialists who graduated from the Academy. At the same time, the Academy became a key structure in the training of highly qualified engineering staff.

\section{CONCLUSION}

Thus, in the late 1920 s - early 1930s, a system for training engineering staff for military shipbuilding was formed and began to develop. This system contributed to the following, firstly, providing enterprises, institutions and shipbuilding industry with specialists, without which it would be impossible to implement shipbuilding programs, including military and five-year plans for their implementation. Secondly, it was impossible to implement the multi-level training of engineering personnel of the highest qualification. Thirdly, the unified training of designers creating new types of equipment and weapons, and their specialists, which allowed the country's leadership to quickly, clearly and flexibly implement and adjust the policy of naval construction.

The uniqueness of this system was also in the fact that all its structural elements were located in one center - Leningrad. The leading enterprises, organizations and institutions of military shipbuilding were also located in Leningrad.

\section{REFERENCES}

[1] Polovinkin V.N., Fedulov S.V., Barbanel' B.A., Solov'yov D.N. Sistema podgotovki inzhenernyh kadrov dlya voennogo korablestroeniya $v 1920$ 1930-e gody: sozdanie $i$ funkcionirovanie. [The system of training engineers for military shipbuilding in the 1920-1930: creation and operation]. Saint Petersburg. Publ. house of Saint Petersburg Electrotechnical University "LETI", 2019. 143 p. (In Russian)

[2] [Russian state archive of the Navy. Fund P-352. Inventory 3. Document 517. (In Russian)

[3] Ocherki istorii Voenno-Morskoj Akademii. [Essays on the History of the Naval Academy]. Edited by A.E.Orel. Leningrad. 1970. 246 p. (In Russian)

[4] Russian state archive of Naval Academy. F.P-352. I. 3. D. 131, 177,185, 212, 291, 518. (In Russian).

[5] Russian state archive of Naval Academy. F.P-352. I. 3. D. 518. (In Russian).

[6] Russian state archive of Naval Academy. F.P-352. I. 3. D. 177. (In Russian).

[7] Russian state archive of Naval Academy. F.P-352. I. 3. D. 185. (In Russian).

[8] Zhurnal sudohodstvo i sudostroenie [Shipping and shipbuilding journal]. Gosstrojizdat Publ. 1934. No.1. (In Russian).

[9] Russian state archive of Naval Academy. F.P-352. I. 3. D. 212. (In Russian).

[10] Russian state archive of Naval Academy. F.P-352. I. 3. D. 291. (In Russian).

[11] Russian state archive of the Navy. F.P-14 83. I. 1. D. 33. (In Russian). 